УДК: 7.032(38)'02; 730

ББК: 85.13

A43

DOI: $10.18688 /$ aa $199-1-7$

A. Corso

\title{
The Statue of Apollo Smintheus by Scopas and the Monumental Policy of the Satrap Artabazos
}

The aim of this article is the study of Late Classical statues which were set up in the northwestern part of Asia Minor and may have been promoted by the same patron ${ }^{1}$.

I begin this research with the cult statue of the sanctuary of Apollo Smintheus near Chryse in the Troad [12, pp. 16-167].

This sanctuary was important as early as in the age of Homer. From the first song of the Iliad we know that the priest of this sanctuary Chryses had a very beautiful daughter, Chryseis, that Agamemnon, the head of the Greek army at Troy, kidnapped her. Chryses went to the Greek camp at Troy to get his daughter back, but Agamemnon scorned him. Thus Chryses asked Apollo to punish Agamemnon, Apollo sent the black death to the Greek army at Troy, a lot of Greeks died until Agamemnon was forced to return the girl to her father (Homer, Iliad 1.11-487) [2, pp. 241-242].

When this area became subjected to Athenian influence, the sanctuary was celebrated by Sophocles with his tragedy Chryses (frgg. 726-729 Lloyd-Jones).

During the archaic and classical times, the cult of the god may have taken place in a grotto identified around $200 \mathrm{~m}$ south of the Hellenistic temple: this grotto, represented on a coin type [12, pp. 98-99], was endowed with a statue inside and another on top of it and is mentioned by Pacuvius (frg. 87) as the crucial focus of this sacred landscape.

In the middle Hellenistic times, a large temple was built in honor of this god: this temple is pseudodypteros and imitates Hermogenes' temple of Artemis Leucophryene at Magnesia (around 230-190 B.C.). The Artemision of Ephesos may have been another source of inspiration, because columnae caelatae, typical of this temple, were adopted also at Chryse: the friezes carved on these drums of columns evoked episodes of the Trojan myth, which was so important for the mythical memory of this sanctuary [12, pp. 15-63].

In this period, the sanctuary was evoked again by Pacuvius in his tragedy Chryses (frgg. 79-118 Warmington), in which he referred to the headland of Mt. Ida (frg. 84), to the rocky appearance of the promontory (frgg. 86-87), to the sacred grotto (frg. 87) and to the oracular function of the sanctuary (frgg. 102-106). The specification that Chryseis had a son, also named Chryses, who also became a priest, may have been a homage to the priests of the sanctuary

This study has been made thanks to a grant of the Lord Marks Charitable Trust, channeled through the Society of Messenian Archaeological Studies. I wish to thank Dr. Lady Marina Marks, chair of the above mentioned trust, Prof. Andrew Stewart, who acted as referee for this grant, and Prof. Petros Themelis who accepted that the grant is channeled via his respected foundation. 
whose mythical ancestors may have been thought to hark back to the age of the Trojan war.

The cult statue stood at the back of the cella of the temple and was colossal. A marble fragment survives: it is a bent leg, probably the right one of the god (Ill. 8) [12, pp. 61-62].

The general shape of the statue is known from local coins (Ill. 9) [12, pp. 93-103]: Apollo was depicted standing, holding a phiale in his right hand and bow in his left hand. The left leg was straight, while the right leg was bent. Thus the retrieved fragment, being a bent leg, must be the right one. On a coin type, a large mouse appeared near the feet of the god: Apollo was thought to have healed the plain around the sanctuary from the infestation of rats, moreover he may have sent the black death to the Greeks at Troy through rats [2, pp. 241-242].

The type of polishing of the surfaces and the expression of the convex plumpness of the flesh shown by this fragment are also found in the marble head of Apollo Palatinus on the Palatine Hill at Rome (Rome, Palatine Museum, no. 35749) (Ill. 10). We know from Propertius (2.31.1-16) that there were two statues of Apollo in this sanctuary: an Apollo dedicated to the victory at Actium in the area sub divo outside the temple and the cult statue inside the temple. The latter was in the middle of a triad, having at the sides statues of Artemis and Leto. Pliny informs that the statue of Artemis was of the late classical sculptor Timotheos (36.31), the statue of Leto was the work of Kephisodotos the Younger, the elder son of Praxiteles (36.24) and that the statue of Apollo in the middle was of Scopas (36.25). Of course these three statues had been brought from the east to Rome. The Libellus de regionibus Urbis Romae, regio $X$ informs that this Apollo came from Rhamnus, which is why it was called Rhamnusius.

Tomei [17, p. 47], Geominy [9, pp. 314-316] and the authors of the entry on Scopas in Der neue Overbeck [18, pp. 432-434] identified this head as that of Scopas' Apollo, thus one of the few surviving originals by the hands of a great classical master. Other scholars - Roccos [14, pp. 571-588] and Tomei who changed her mind [16, pp. 413-414] — identify the head as that of the Apollo dedicated to the victory at Actium.

However, the surface of the head, where it is preserved, is very fresh, thus it was not outside the temple: in that case it would be much more weathered. The reason why some scholars identified this Apollo with that of Actium, is its colossal size: inside the temple such a tall statue would have nearly reached the roof. However, even the Zeus of Olympia nearly reached the roof in the temple of Zeus at Olympia [10, pp. 120-125], thus this was not a concern of ancient patrons, especially when they brought a statue in a temple which had not been built in the same time of the statue.

Thus this head is that of the statue of Scopas, brought from Rhamnus to the Palatine.

The quality of the head is truly outstanding, as it is shown by the very skilful rendering of the eye-socket. These characteristics make the surviving fragment of Apollo Smintheus stylistically very close to that of Scopas' Apollo Rhamnusius from the Palatine Hill.

The sculptor of Apollo Smintheus is known from two passages of ancient authors. Strabo (13.1.48) and Eustathius (Commentarii ad Homeri Iliandem 1.39) write that the statue was of Scopas and that the mouse was below the foot of the statue. Probably the mouse was placed near the left foot on the above mentioned coin type in order to increase its visibility in the small image of the coin.

The statue of Scopas may have been set up originally in the grotto and in a later moment brought to the Hellenistic temple. 
Concerning the patron of the statue, we should observe that this Apollo conveyed an anti-Greek message because he was thought to have sent the black death against the Greeks at Troy, thus he may hardly have been promoted by a Greek patron. We can recall that the Smintheion was inside the satrapy of Hellespontine Phrygia, whose capital was Dascylium [1, pp. 700-720]: the Smintheion in the period of Scopas was under Persian rule. Thus, it is likely that the project was a satrapic enterprise, of someone who sided with the Trojans and not with the Greeks.

This satrapy was adorned also with other statues by renowned Greek late classical sculptors. Clearly, late classical satraps of this region, as the Hekatomnids

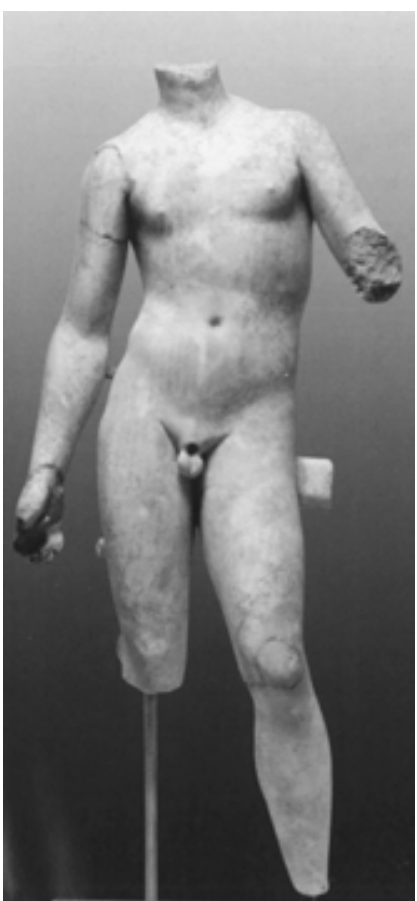

Fig.1. Praxiteles. Marble statue of Eros. Late Hellenistic copy. Archaeological Museum, Kos. Photo by A. Corso

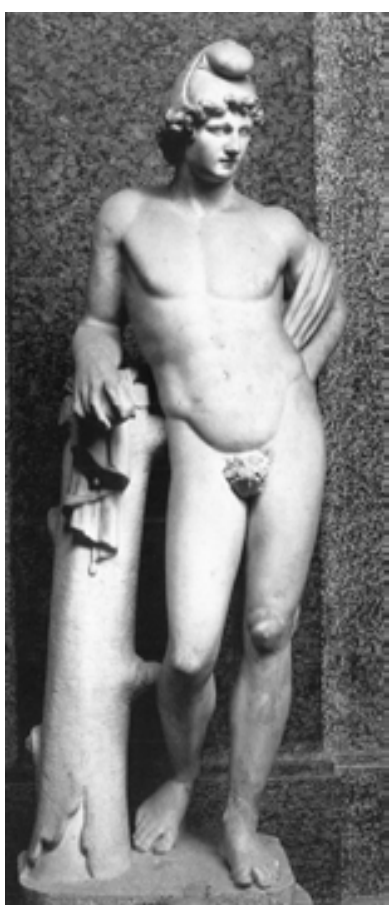

Fig. 2. Euphranor. Marble statue of Paris. Roman copy. Galleria Borghese, Rome. Photo courtesy of Prof. P. Moreno in Caria, endowed their territory with works by the best Greek masters.

One of these masterpieces was the Eros of Parion by Praxiteles, also in marble, recorded by Pliny (36.22), represented on coins of Parion and recognized in the Kos type of Eros since the images on coins and of the statue on Kos are basically the same [6, pp. 65-75] (Fig. 1). Several testimonia show that the Eros of Parion was the Eros of Paris, the hero gynai(ko)manes, mad for women. Paris was said to have been sent off from Troy while still a baby and to have grown as a shepherd at Parion [8, pp. 56-58, 91-92].

The S-shaped style and the velvety skin of this Eros advertize an androgynous ideal of male youths, which is in complete opposition to the muscular ideal of young men which was typical of the Peloponnesian tradition.

The bronze statue of Paris by Euphranor probably also stood in Parion. This Paris is described by Pliny (34.77): he was represented as the judge of the three goddesses, the lover of Helen and the killer of Achilles. No Greek would have commissioned a statue of Paris as the slayer of the beloved Greek hero Achilles. Thus even this statue may have been a satrapic dedication and perhaps coincides with the bronze statue of Paris seen by Athenagoras in the agora of Parion (Legatio pro Christianis 26). Paris was honored at Parion with festivities and sacrifices. The statue is recognized in the Borghese type of Paris (Fig. 2): again a soft, velvety figure, typical of the tradition of Asia Minor [4, pp. 153-162]. 
Finally, Apollo was represented for a very long period with the style of Praxiteles' Apollo Sauroctonus on coin types of Apollonia ad Rhyndacum, a Milesian colony which in this period was also under Persian rule and in the same satrapy [6, pp. 22-65]. This fact leads to the suggestion that Praxiteles' bronze

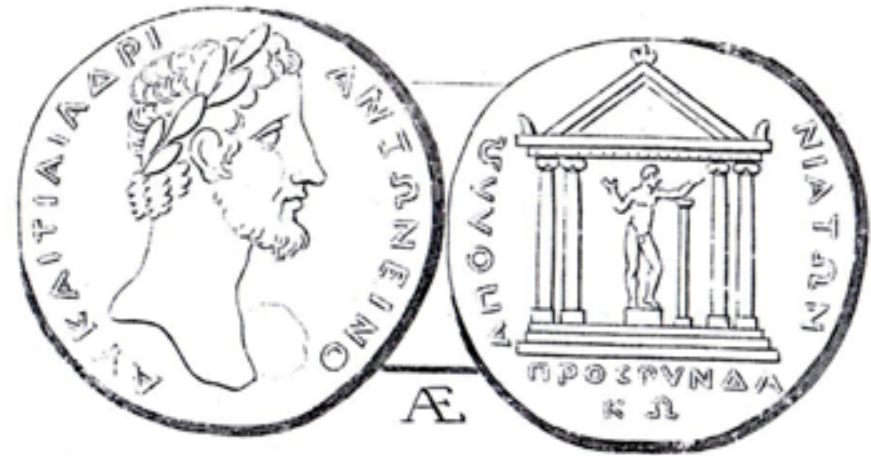

Fig. 3. AE Coin of Apollonia ad Rhyndacum. Empire of Antoninus Pius. Drawing taken from Sestini D. Descrizione delle medaglie antiche greche del Museo Hedervariano, vol. 2. Florence, Guglielmo Piatti, 1828, pl. 3., fig. 5 statue of Apollo Sauroctonus was set up in the temple of Apollo of this town (Fig. 3). The objection that on these coins an Ionic column substitutes the tree-trunk at the side of Apollo calls for an explanation. The alternation of columns and tree trunks as side supports of the main figure are known for other statue types as well. One example is the copyist tradition of Apollo Lycius [13, pls. 119-128]. Another example would be the Cnidian Aphrodite, whose image was reproduced with a clay figurine from Pergamum with a column in the place of the vessel at the left side of the goddess [5, p. 91, fig. 60]. Probably columns sometimes substituted other side supports of statues of deities because they underlined the pertinence of these images to sacred landscapes.

Apollo Sauroctonus was represented as a teenager, endowed with an S-shaped style and again with a velvety and androgynous appearance: probably this creation portrays the god when he was shepherd of his lover, king Admetus of Thessaly. The circumstance that Admetus took part in Jason's expedition to Colchis explains the popularity of this sculptural type in the area of the Black Sea. When Apollonia became Christian, St. George killing the dragon took the place of Apollo [6, pp. 22-65].

The satrap who commissioned all these creations may have been Artabazos: satrap from 362 B.C., he revolted against the Great King of Persia, thus constituting his satrapy as an independent kingdom, in the 350s [11, p. 44]. In order to resist the army of the Great King he hired the Athenian general Chares who supported Artabazos with an army of Greek mercenaries [15, pp. 1097-1098]. Perhaps through Chares he was introduced to the most important workshops of sculptors settled at Athens, such as those of Scopas, Praxiteles and Euphranor.

Any state needs a founding myth in order to get legitimacy for its existence: the founding myth of this state may have been the memory of Troy. Likewise, in the same period, the Hekatomnids endowed the Mausoleum at Halikarnassos with an Amazonomachy [3, pp. 42-64] which exalted the Amazons as symbols of Asia. Thus this type of re-use of myths was not unknown in the context of the monumental enterprises of satraps of this age.

From a philosophical point of view, it is noteworthy that the philosopher Eudoxos of Knidos was at the time in Cyzikos [7, pp. 223-225]. He asserted a hedonistic idealism and that pleasure was the highest idea. Thus he may have given philosophical legitimacy to the above considered art of pleasure. 


\section{References}

1. Briant P. Histoire de l'Empire Perse. Paris, Fayard Publ., 1996. 1247 p. (in French).

2. Chiai G. F. Troia, la Troade e il nord Egeo nelle tradizioni mitiche greche. Paderborn, Brill Deutschland Publ., 2017. 315 p. (in Italian).

3. Cook B. F. Relief Sculpture of the Mausoleum at Halicarnassus. Oxford, Oxford University Press Publ., 2005. 125 p.

4. Corso A. La statua in bronzo di Paride opera di Eufranore. Rendiconti dei Lincei, 2018, vol. 29, pp. 153-162 (in Italian).

5. Corso A. The Art of Praxiteles II. Rome, L'Erma di Bretschneider Publ., 2007. 303 p.

6. Corso A. The Art of Praxiteles IV. Rome, L'Erma di Bretschneider Publ., 2013. 257 p.

7. Folkerts M. Eudoxos [1]. Der neue Pauly, 1998, vol. 4, pp. 223-225 (in German).

8. Frisch P. Die Inschriften von Parion. Bonn, GMBH Publ., 1983. 107 p. (in German).

9. Geominy W. Skopas. Enciclopedia dell'Arte Antica, suppl. 2, vol. 5. Rome, Istituto della Enciclopedia Italiana Publ., 1997, pp. 314-316 (in Italian).

10. Hennemeyer A. Der Zeus-Tempel von Olympia. Mythos Olympia. Berlin, Institutum Archaeologicum Germanicum Publ., 2012, pp. 120-125 (in German).

11. Kuhrt A. Artabazos [4]. Der neue Pauly, 1997, vol. 2, p. 44 (in German).

12. Özgünel A. C. (ed.). Smintheion. In Search of Apollo Smintheus. Istanbul, Ege Yayınları Publ., 2015. 167 p.

13. Rizzo G. E. Prassitele. Milan, Treves Publ., 1932. 121 p. (in Italian).

14. Roccos L. J. Apollo Palatinus. American Journal of Archaeology, 1989, vol. 93, pp. 571-588.

15. Schmitz W. Chares [1]. Der neue Pauly, 1997, vol. 2, pp. 1097-1098 (in German).

16. Tomei M. A. Il monumento celebrativo della battaglia di Azio sul Palatino. Melanges de l'Ecole Francaise de Rome, 2017, vol. 129, 2, pp. 413-424 (in Italian).

17. Tomei M. A. Museo Palatino. Rome, Electa Publ., 1997. 159 p. (in Italian).

18. Vorster C. et al. Skopas von Paros. Der neue Overbeck, vol. 3. Berlin, De Gruyter Publ., 2014, pp. 417-470 (in German).

Title. The Statue of Apollo Smintheus by Scopas and the Monumental Policy of the Satrap Artabazos.

Author. Antonio Corso - Dr., researcher. Society for the Messenian Archaeological Studies, 33 Psaromilinkou, GR10553, Athens, Greece.padua-athens@hotmail.com

Abstract. In this article, the surviving fragment of Scopas' statue of Apollo Smintheus in Troad is considered. The sacred landscape in which the statue was set up, the history of this sanctuary and its possible political patronage are analyzed. The colossal masterpiece may have been promoted by Artabazos, the satrap of Hellespontine Phrygia of the middle of the $4^{\text {th }}$ century B.C. This satrap may have promoted also the Eros by Praxiteles at Parion, the Paris by Euphranor at Parion and the Apollo Sauroktonos by Praxiteles at Apollonia ad Rhyndacum. He may have been introduced to important workshops of sculptors based in Athens thanks to his alliance with the Athenian general Chares. The philosopher Eudoxos settled in Cyzikos may have provided the philosophical background of this art of pleasure.

Keywords: Apollo Smintheus; Chryses; Chryseis; Scopas; Artabazos; Praxiteles; Euphranor; Chares; Eudoxos of Cnidus.

Название статьи. Статуя Аполлона Сминфея Скопаса и политика установки монументов сатрапа Артабаза.

Сведения об авторе. Корсо Антонио - full doctor, научный сотрудник. Общество археологических исследований Мессинии. Псаромилинкои, 33, GR10553, Афины, Греция. padua-athens@hotmail.com

Аннотация. В статье рассматривается сохранившийся фрагмент статуи работы Скопаса, созданной для храма Аполлона Сминфея в Троаде, в контексте сакрального ландшафта и политического патроната святилища. В качестве гипотетического заказчика выдвигается Артабаз, сатрап Геллеспонтской Фригии в середине IV в. до н. э. Возможно, по его же заказу был создан целый ряд знаменитых статуй: в Парии Эрот Праксителя и статуя Париса Эвфранора, а также Аполлон Савроктон Праксителя в Аполлонии. Посредником между Артабазом и скульптурными мастерскими мог выступать его союзник афинский полководец Харес. Особый гедонистический идеал этих статуй, возможно, отражает идеи философа Евдокса, проживавшего в это время в Кизике.

Ключевые слова: Аполлон Сминфей; Хрис; Хрисеида; Скопас; Артабаз; Пракситель; Эвфранор; Харес; Евдокс Книдский. 


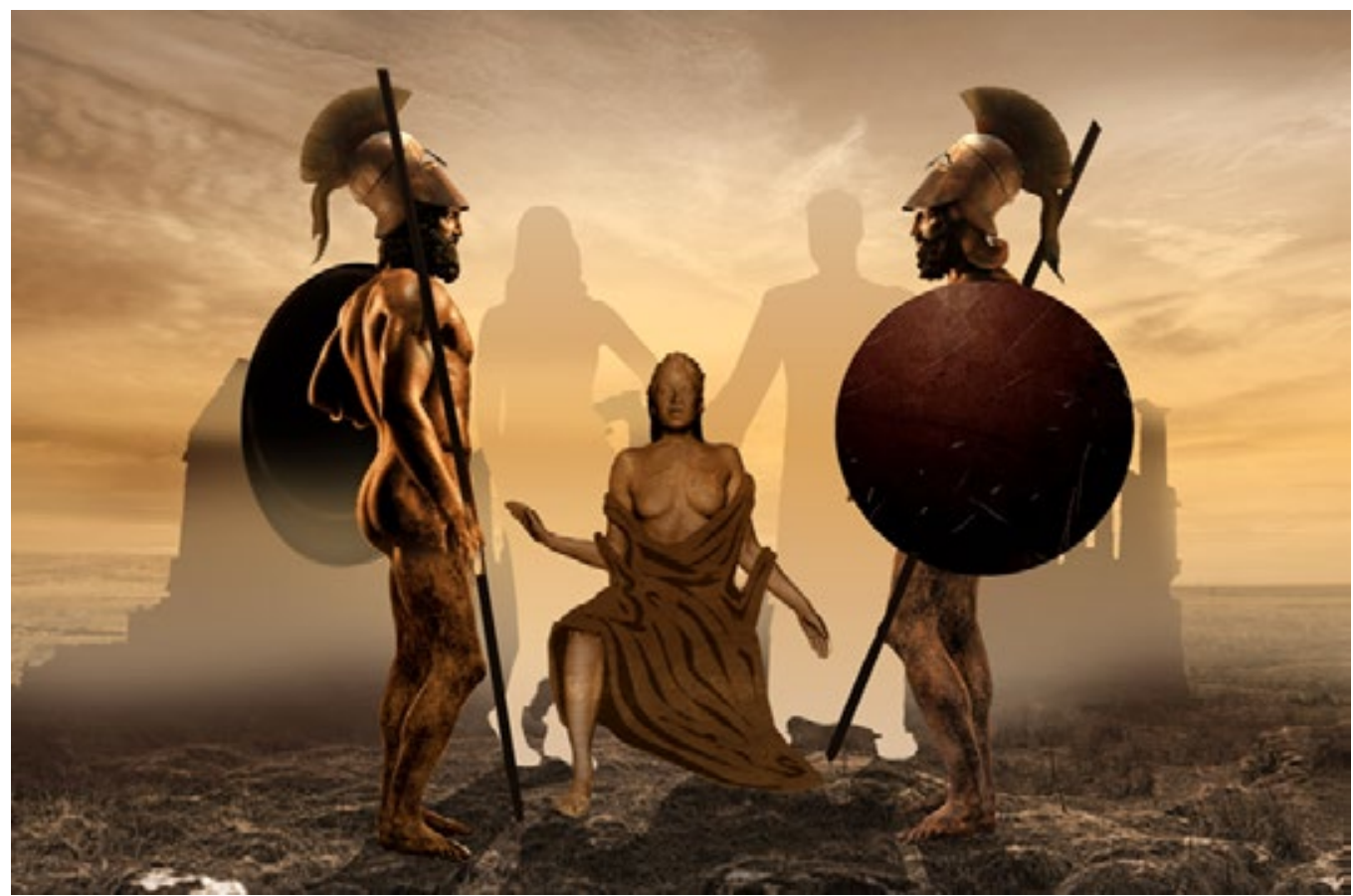

III. 7. The Fratricides group made by Pythagoras of Rhegion. Reconstruction by Daniele Castrizio

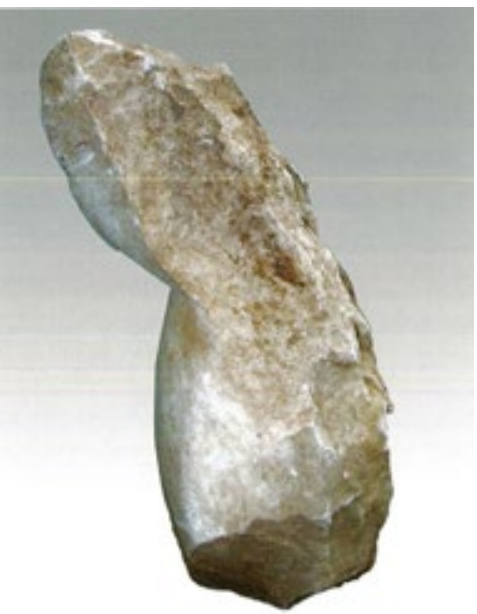

III. 8. Scopas. Leg of cult statue of Apollo Smintheus. Probably around 350 B.C. Museum, Guelpinar. From: Oezguenel A. C. (ed.). Smintheion. Istanbul, ICDAS, 2015 , p. 61

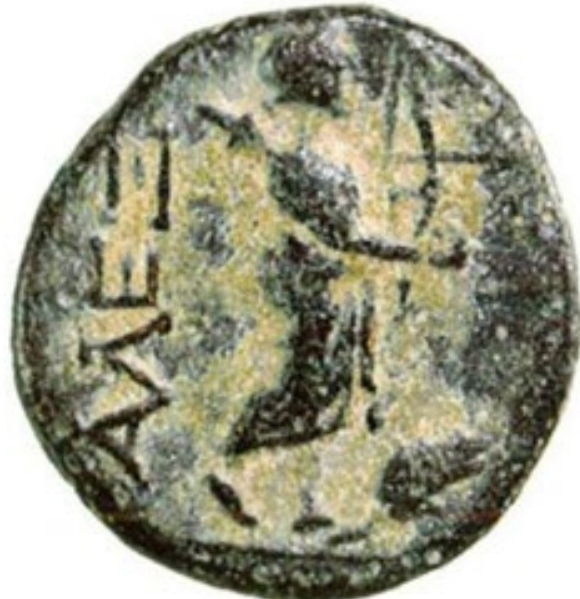

III. 9. AE Coin of Alexandria Troas. Around 300 a. C. The British Museum, Department of Coins. London. From: Oezguenel A. C. (ed.). Smintheion. Istanbul, ICDAS, 2015, p. 95 


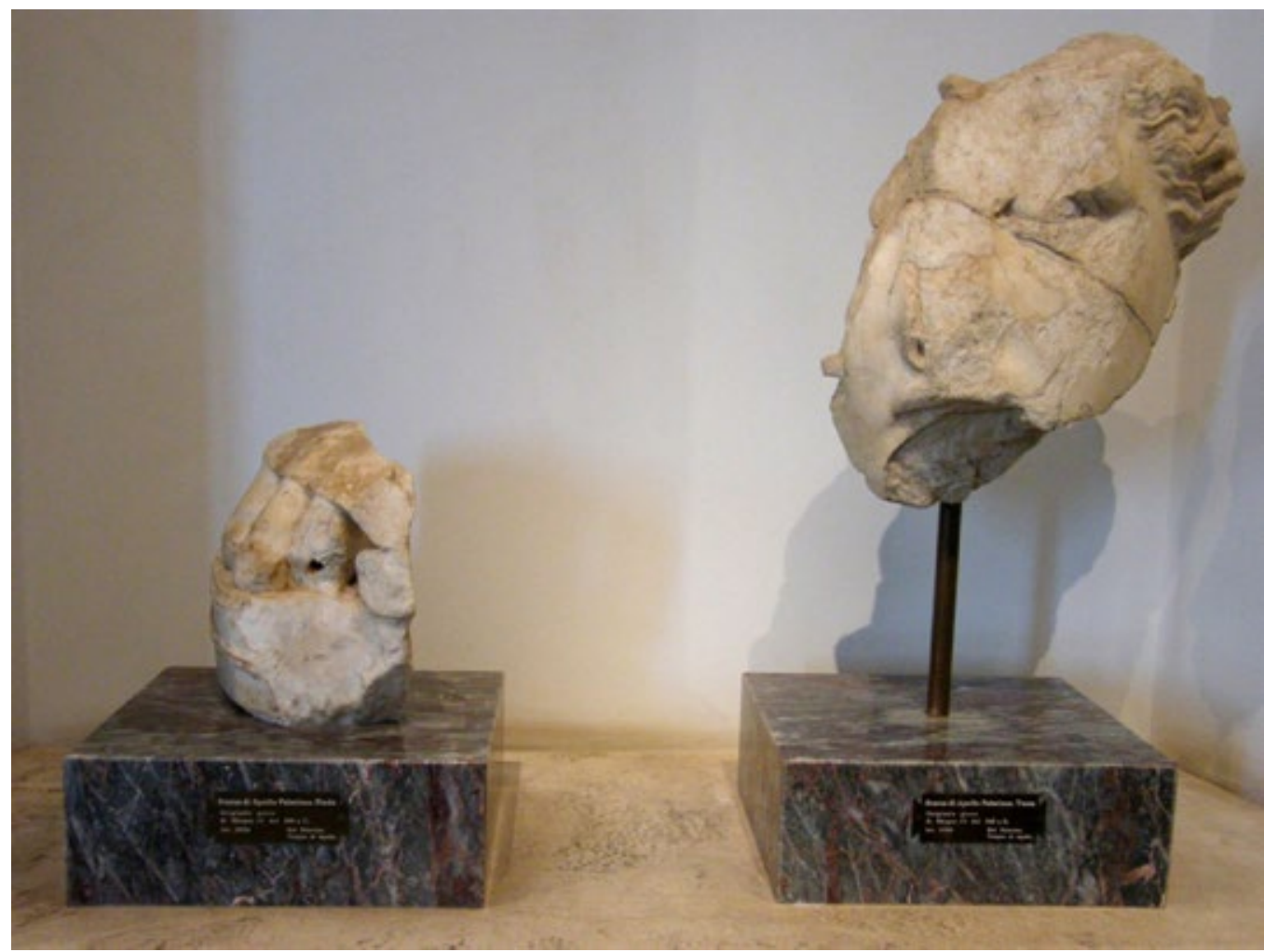

III. 10. Scopas. Head and foot of marble statue of Apollo Rhamnusius. Palatine Museum, Rome. Photo courtesy of Dr. M. A. Tomei

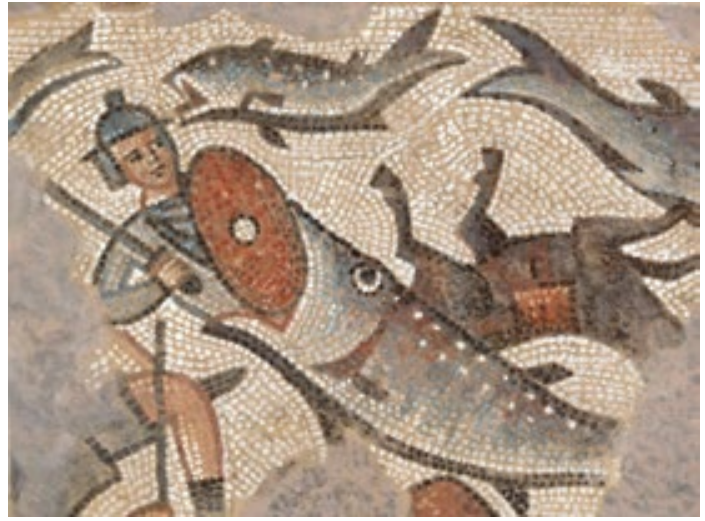

III. 13. The Huqoq mosaic pavement. A scene of an Egyptian warrior who perishes. Sketch by A. P. Frolov

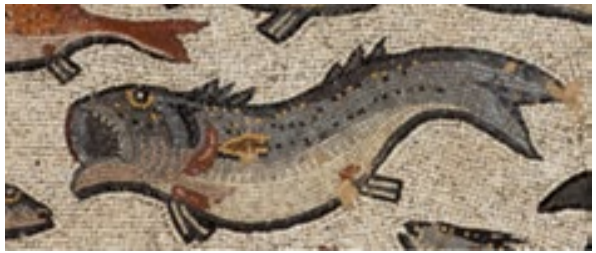

III. 11. The Lod mosaic pavement. A fragment presenting fish

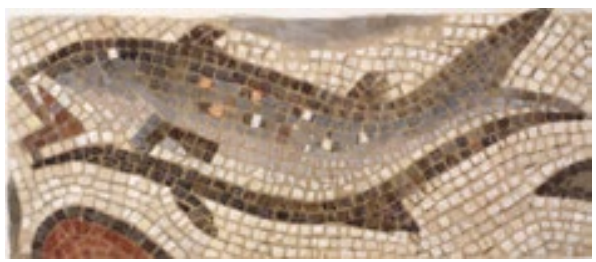

III. 12. The Huqoq mosaic pavement. A fragment presenting fish. Sketch by A. P. Frolov 